\title{
The cytotoxicity study of praziquantel enantiomers
}

This article was published in the following Dove Press journal:

Drug Design, Development and Therapy

24 June 2016

Number of times this article has been viewed

\section{Qian Sun \\ Ruifeng Mao \\ Dongling Wang \\ Changyan $\mathrm{Hu}$ \\ Yang Zheng \\ Dequn Sun}

Department of Pharmacy, Marine College, Shandong University, Weihai, People's Republic of China
Correspondence: Dequn Sun

Marine College, Shandong University,

Weihai, No 180, Wenhua West Road,

Weihai 264209, People's

Republic of China

Tel +86 63I 5688303

Email dequn.sun@sdu.edu.cn
Abstract: Praziquantel (PZQ) is prescribed as a racemic mixture (racemic-PZQ, rac-PZQ), which is composed of $(R)$-PZQ and $(S)$-PZQ. In this work, the cytotoxicity of rac-PZQ and its two enantiomers $(R)$-PZQ and (S)-PZQ on eight cell lines (L-02, HepG2, prf-plc-5, SH-SY5Y, HUVEC, A549, HCT-15, Raw264.7) was evaluated by 3-(4,5-dimethylthiazol-2-yl)-2,5-diphenyltetrazolium bromide and lactate dehydrogenase assays. The morphology of apoptotic cells was studied by fluorescence microscope using Hoechst 33342 staining, and the cytotoxicity of the compounds was also tested by lactate dehydrogenase assay. Results revealed that $(R)-\mathrm{PZQ}$ had negligible cytotoxicity against L-02, SH-SY5Y, HUVEC, A549, HCT-15, and Raw264.7 cells but selectively inhibited tumor cell lines (prf-plc-5 and HepG2). However, in contrast to $(R)$-PZQ, the $(S)$-isomer showed higher cytotoxicity against L-02 cells and lower inhibition on prf-plc-5 and HepG2 cells. Besides, $(R)-\mathrm{PZQ}$ showed lower cytotoxicity on SH-SY5Y cells than $(S)$-PZQ. Meanwhile, $(R)$-PZQ at $<80 \mu \mathrm{M}$ concentration could promote proliferation of macrophage cells (Raw264.7). Our research revealed that $(R)$-PZQ has lower cytotoxicity than $(S)$-PZQ and has similar cytotoxicity with rac-PZQ. (S)-PZQ is the principal enantiomer to cause side effects on human definitive hosts. These findings gave the reasonable reasons for World Health Organization to produce $(R)$-PZQ as a replacement for $r a c$-PZQ for the treatment of schistosomiasis.

Keywords: isomer, MTT, selectivity, $(R)-\mathrm{PZQ}$

\section{Introduction}

Schistosomiasis is still endemic in $>70$ countries and territories, especially in tropical and subtropical regions. ${ }^{1,2}$ Nowadays, $\sim 200$ million people are infected with schistosomiasis, with 650 million people at a risk of infection all over the world. Over the past 40 years, several drugs have been used for the treatment of schistosomiasis, ${ }^{3-5}$ but until today, the most important drug that is used in clinics to control all forms of schistosomiasis is only praziquantel (PZQ). Every year $>300$ metric tons of PZQ are produced for intensive mass treatment for all forms of schistosomiasis. The resistance and adverse reactions with the long-term use of PZQ have been reported since $1970 \mathrm{~s} .{ }^{6-10}$

PZQ is prescribed as a racemic mixture, which is composed of $(R)-\mathrm{PZQ}$ and $(S)-\mathrm{PZQ}$ (Figure 1). It is well known that $(R)$-PZQ possesses an antischistosoma effect; the tegumental damage and paralytic muscular contraction of parasites rely solely on the $(R)-\mathrm{PZQ}$, whereas $(S)-\mathrm{PZQ}$ is a toxic enantiomer and ineffective against worms. ${ }^{11}$ The Special Programme for Research and Training in Tropical Diseases Research has assigned the low-cost preparation of $(R)$-PZQ as a key priority for future research. ${ }^{12}$ Woelfle et $\mathrm{al}^{13}$ had reported the preparation of chiral PZQ by resolution strategy. So far, research and development of chiral PZQ have been carried out in order to decrease the pill dose, reduce the side effects, ${ }^{14}$ and remove the bitter taste of pill mainly caused by $(S)-\mathrm{PZQ} \cdot{ }^{15}$ Recently, the metabolic profiling of chiral PZQ was studied by our group to reveal the in silico, in vitro, and in vivo enantioselective metabolic differences of PZQ enantiomers, ${ }^{16}$ and the 


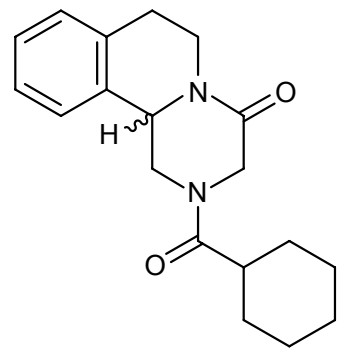

rac-PZQ

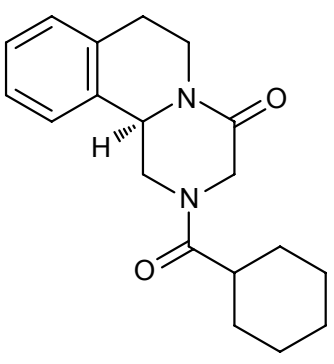

(R)-PZQ

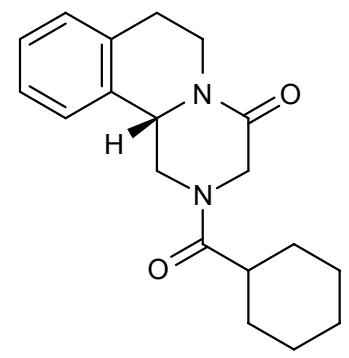

(S)-PZQ

Figure I rac-PZQ and its enantiomers.

Abbreviations: rac-PZQ, racemic praziquantel; PZQ, praziquantel.

toxicity study in vitro is also important to improve usage of the drug in effective, safe, and economic way.

\section{Materials and methods Synthesis of (R)-PZQ, (S)-PZQ, and rac-PZQ}

$(R)-\mathrm{PZQ}$ and $(S)-\mathrm{PZQ}$ were obtained with an improved method based on the reported procedure, ${ }^{17}$ with the enantiomeric excess value $>99 \%$ by high-performance liquid chromatography.

\section{Cell lines}

All the eight cell lines were provided by Shanghai Institute of Cellular Biology of Chinese Academy of Sciences. This study was performed with the approval of the Institutional Ethics Committee of Shandong University.

\section{Cell culture}

HepG2, SH-SY5Y, and Raw264.7 cell lines were maintained in Dulbecco's Modified Eagle's Medium supplemented with $10 \%$ fetal bovine serum and $1 \%$ penicillin and streptomycin. The L-02, prf-plc-5, human umbilical vein endothelial cell (HUVEC), A549, and HCT-15 cells were maintained in RPMI 1640 supplemented with 10\% fetal bovine serum and $1 \%$ penicillin and streptomycin. The cells were grown at $37^{\circ} \mathrm{C}$ in an environment of $5 \% \mathrm{CO}_{2}$.

\section{In vitro antiproliferative assay (MTT assay)}

The in vitro cytotoxicity of the enantiomers and racemic mixtures of PZQ against HepG2, SH-SY5Y, Raw264.7, L-02, prf-plc-5, HUVEC, A549, and HCT-15 cell lines was measured by an assay based on the cleavage of the yellow tetrazolium salt 3-(4,5-dimethylthiazol-2-yl)-2, 5-diphenyltetrazolium bromide (MTT) (Sigma-Aldrich Co., St Louis, MO, USA) to form purple formazan crystals in viable cells. The compounds were dissolved in dimethyl sulfoxide (DMSO) and diluted with culture medium. The cells cultured in the exponential growth phase were treated with different concentrations $(2.5 \mu \mathrm{M}, 5 \mu \mathrm{M}, 10 \mu \mathrm{M}, 20 \mu \mathrm{M}$, $40 \mu \mathrm{M}, 80 \mu \mathrm{M}, 160 \mu \mathrm{M})$ of PZQ enantiomers at a density of $5 \times 10^{4}$ cells $/ 100 \mu \mathrm{L}$ per well and incubated for 48 hours at $37^{\circ} \mathrm{C}$ in $5 \% \mathrm{CO}_{2}$ incubator. The cells were then treated with $10 \%$ volume ratio (v/v) MTT dye solution $(5 \mathrm{mg} / \mathrm{mL})$ for 4 hours. The medium with MTT solution was replaced with DMSO $(100 \mu \mathrm{L})$. The 96-well culture plates were then gently shaken in the dark for 30 minutes, and absorbance at $570 \mathrm{~nm}$ and $630 \mathrm{~nm}$ (background) was measured with a microtiter plate reader. The negative (cells and solvent) and positive (cells treated with rac-PZQ) controls were run in parallel. All assays were carried out in triplicate. The results were expressed in terms of $\mathrm{IC}_{50}(\mu \mathrm{M})$ and are summarized in Table 1, and the inhibition rates under different drug concentrations on the eight cell lines are shown in Figure 2.

\section{Hoechst 33342 staining}

Four cell lines (L-02, HepG2, prf-plc-5, and SH-SY5Y) were chosen for Hoechst 33342 staining. After the incubation period, these four cell lines were rinsed with phosphate-buffered saline (PBS) and incubated with $5 \mu \mathrm{g} / \mathrm{mL}$ Hoechst 33342 (SigmaAldrich Co.) in $1 \mathrm{~mL}$ culture medium at $37^{\circ} \mathrm{C}$ under $5 \% \mathrm{CO}_{2}$ for 20 minutes, and then the cell cultures were rinsed with PBS again. Cells were examined under a fluorescent microscope (Nikon eclipse, TE2000-U; Nikon Corporation, Tokyo, Japan). The number of apoptotic cells was calculated by counting Hoechst 33342-stained cells with shrunken nuclei in five random fields in each well with three wells per group. The morphological changes of apoptotic cells in nuclei and nuclear chromatin and the inhibition rates under different drug concentrations on the four cell lines (bar graph) are displayed in Figure 3.

\section{Lactate dehydrogenase assay}

To further confirm the cytotoxicity of compounds $(R)-\mathrm{PZQ}$, $(S)-P Z Q$, and rac-PZQ against the eight cell lines, cell death 
Table I In vitro cytotoxicity of (R)-PZQ, (S)-PZQ, and rac-PZQ against eight cancer cell lines

\begin{tabular}{|c|c|c|c|c|c|c|c|c|}
\hline \multirow[t]{2}{*}{ Compounds } & \multicolumn{8}{|l|}{$I C_{50}(\mu M)^{a}$} \\
\hline & L-02 & HepG2 & prf-plc-5 & SH-SY5Y & HUVEC & A549 & HCT-I 5 & Raw264.7 \\
\hline rac-PZQ & $106.0 \pm 2.0^{\mathrm{b}}$ & $165.3 \pm 3.7$ & $>200$ & $>200$ & $>200$ & $>200$ & $>200$ & $>200$ \\
\hline (R)-PZQ & $>200 * *$ & $64.2 \pm 1.8 * *$ & $17.0 \pm 1.2^{* *}$ & $>200$ & $>200$ & $>200$ & $>200$ & $>200$ \\
\hline (S)-PZQ & $80.4 \pm 1.9 * *$ & $123.4 \pm 2.5^{*}$ & $>200$ & $163.2 \pm 3.9$ & $>200$ & $>200$ & $>200$ & $>200$ \\
\hline
\end{tabular}

Notes: ${ }^{2}$ The cells were continuously treated with different concentrations ( $\left.5 \mu \mathrm{M}, 10 \mu \mathrm{M}, 20 \mu \mathrm{M}, 40 \mu \mathrm{M}, 80 \mu \mathrm{M}, 160 \mu \mathrm{M}\right)$ of PZQ enantiomers for 48 hours; PZQ samples dissolved in DMSO. Cell viability was then determined by MTT assay. ${ }^{b} A l l$ data are expressed as means from three separate determinations. IC ${ }_{50}$ values $($ mean \pm SEM) were given only if they were $<200 \mu \mathrm{M}$. $* P<0.05$, $* * P<0.0$ I.

Abbreviations: rac, racemic; PZQ, praziquantel; DMSO, dimethyl sulfoxide; MTT, 3-(4,5-dimethylthiazol-2-yl)-2,5-diphenyltetrazolium bromide; SEM, standard error of the mean.
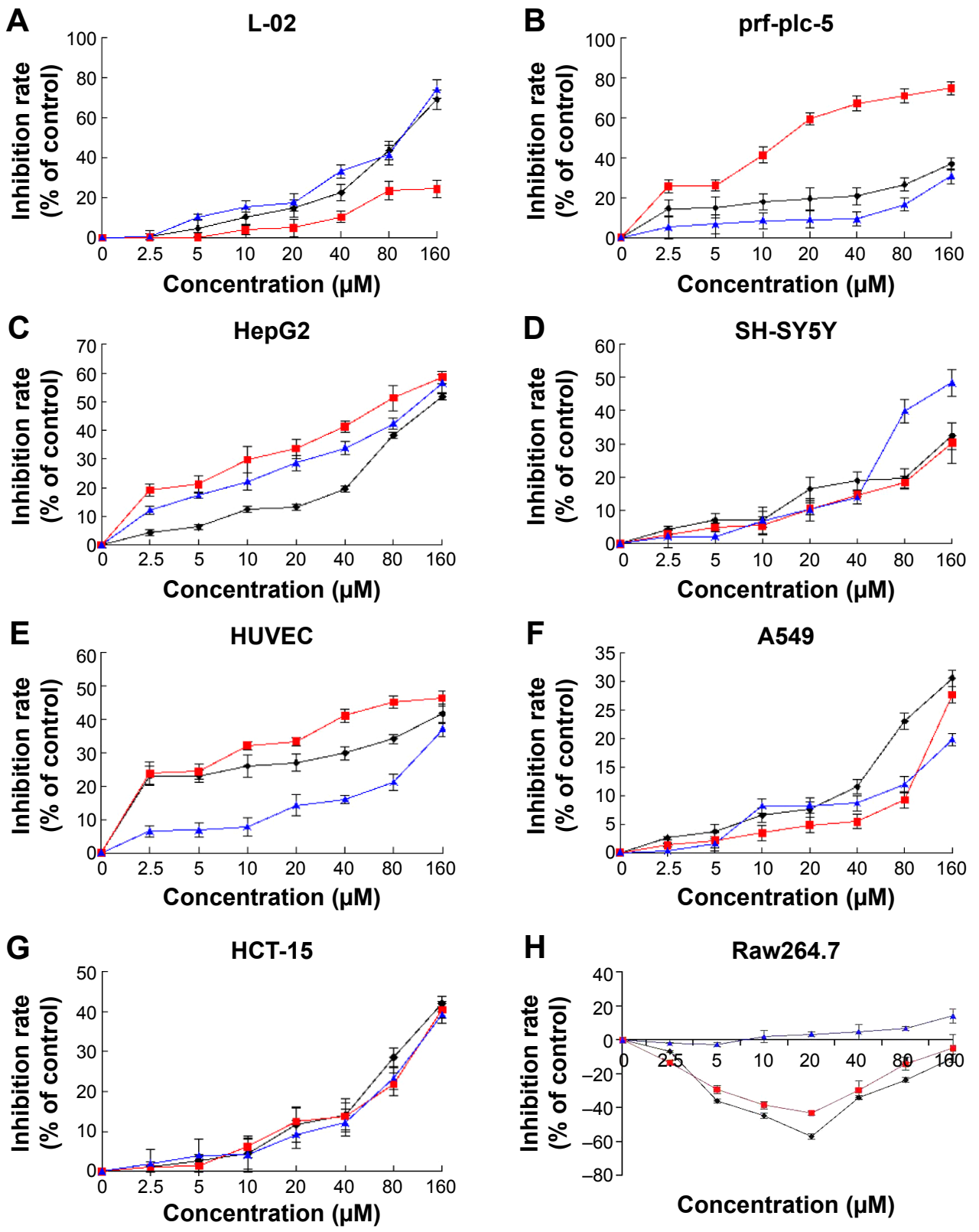

Concentration $(\mu \mathrm{M})$

$$
\rightarrow \text { rac-PZQ } \rightarrow(R)-\mathrm{PZQ} \nrightarrow(S)-\mathrm{PZQ}
$$

Figure 2 The proliferation inhibition of (R)-PZQ, (S)-PZQ, and rac-PZQ assayed by MTT.

Notes: These eight cell lines were continuously treated with different concentrations $(2.5 \mu \mathrm{M}, 5 \mu \mathrm{M}, 10 \mu \mathrm{M}, 20 \mu \mathrm{M}, 40 \mu \mathrm{M}, 80 \mu \mathrm{M}, 160 \mu \mathrm{M})$ of PZQ enantiomers for 48 hours. (A) L-02 cell line, (B) prf-plc-5 cell line, (C) HepG2 cell line, (D) SH-SY5Y cell line, (E) HUVEC cell line, (F) A549 cell line, (G) HCT-I5 cell line, and (H) Raw264.7 cell line. Cell viability was then determined by MTT assay. $P<0.05$ at all compound concentrations.

Abbreviations: PZQ, praziquantel; rac, racemic; MTT, 3-(4,5-dimethylthiazol-2-yl)-2,5-diphenyltetrazolium bromide. 

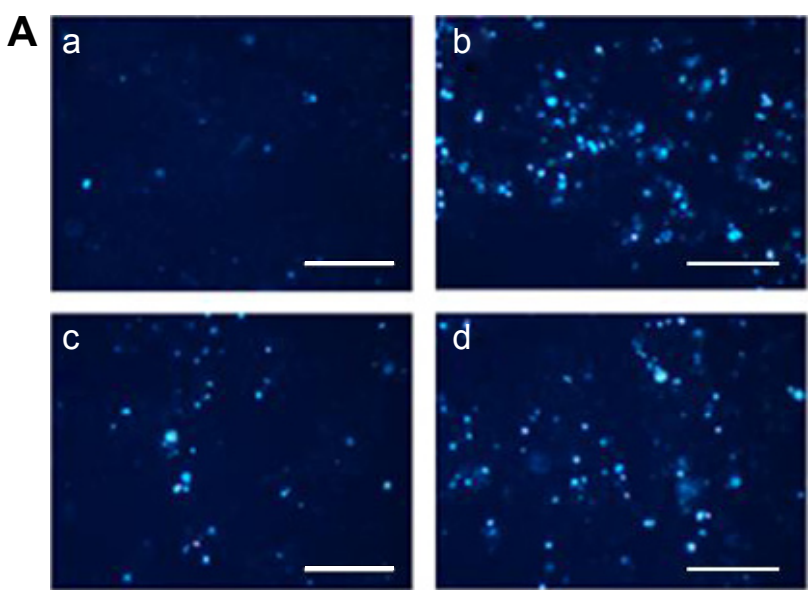

L-02
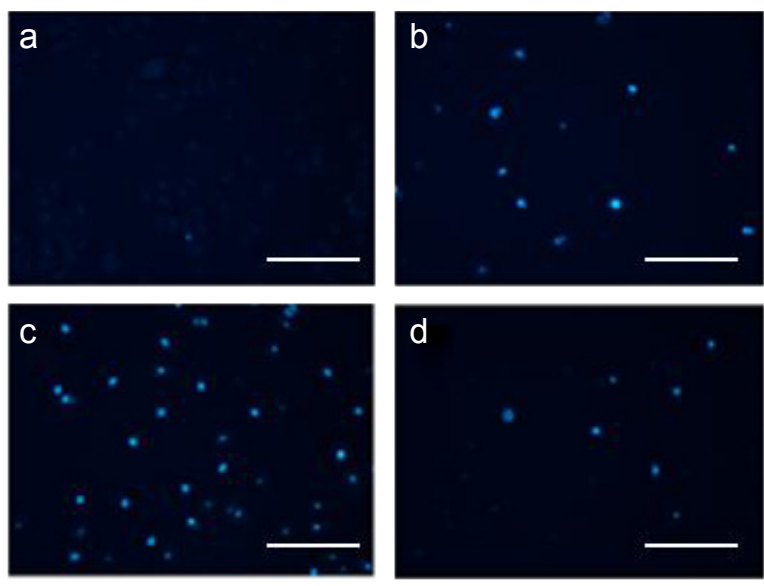

HepG2

B

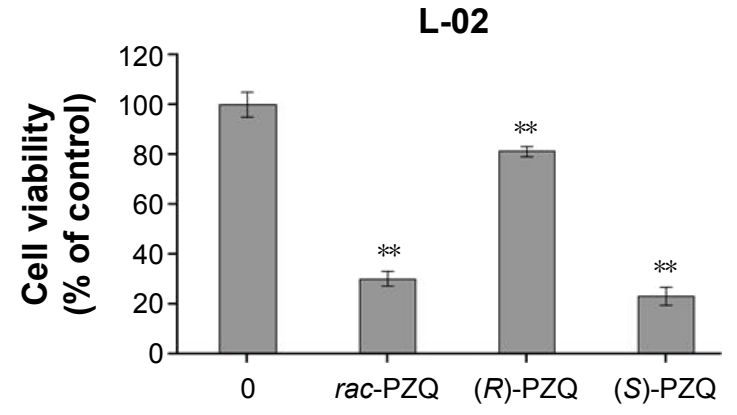

HepG2

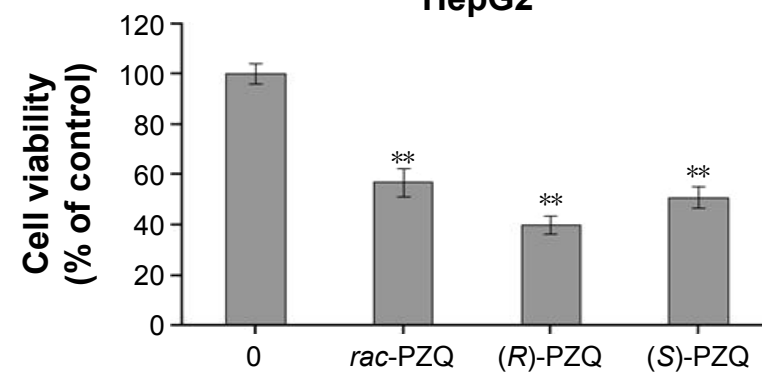

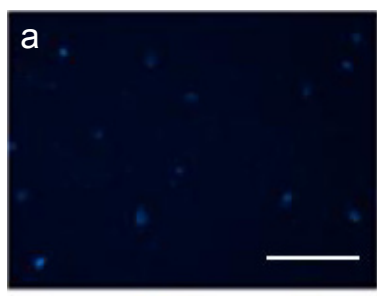
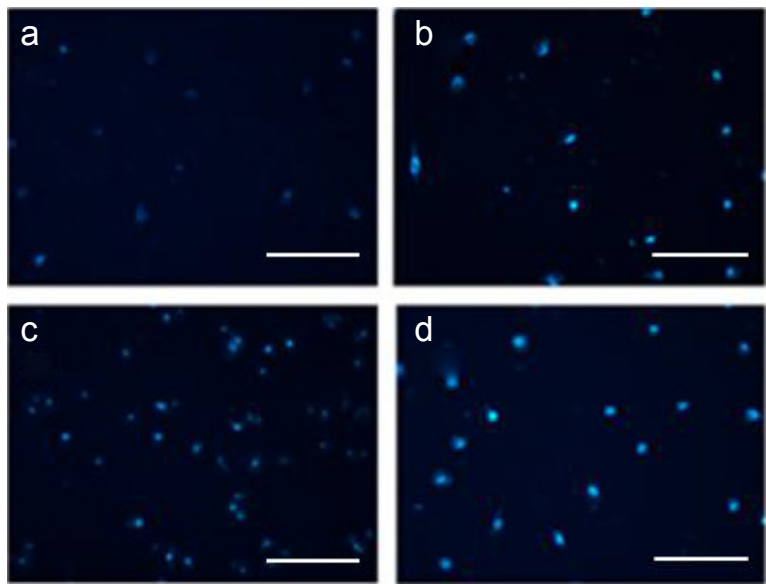

prf-plc-5
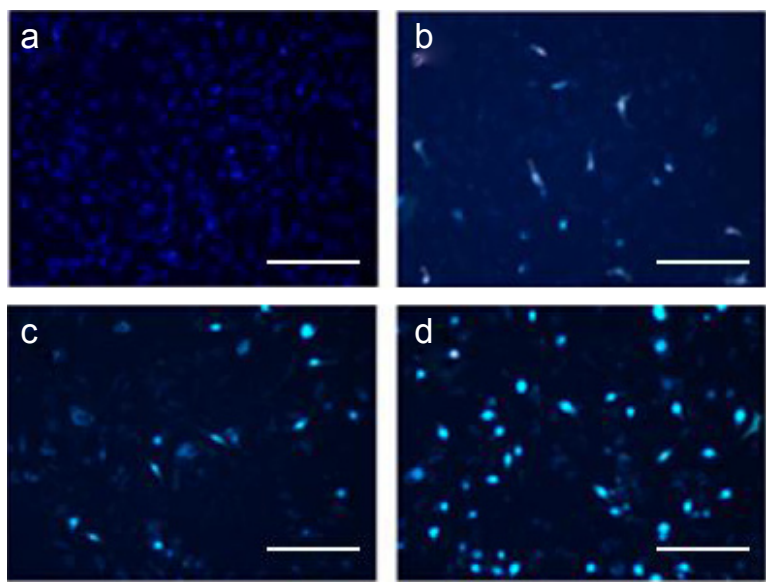

SH-SY5Y

prf-plc-5

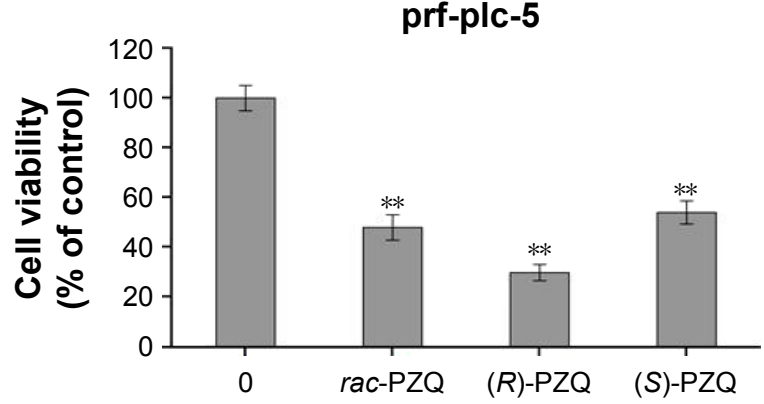

SH-SY5Y

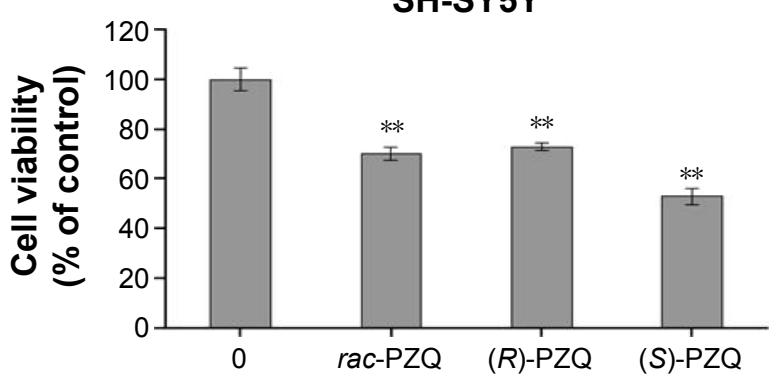

Figure 3 Fluorescent microscopic analysis of nuclei fragmentation by Hoechst 33342 staining.

Notes: Representative photomicrographs of four cell lines (L-02, HepG2, prf-plc-5, and SH-SY5Y) stained with Hoechst 33342 fluorescent dye after exposure to rac-PZQ, $(R)-P Z Q$, and (S)-PZQ (drug concentrations were $0 \mu \mathrm{M}$ and $160 \mu \mathrm{M}$ ) for 48 hours, respectively. The normal cells exhibited pale blue fluorescence and the apoptotic cells exhibited strong blue fluorescence. Magnification $\times 200$, scale bars $=50 \mu \mathrm{m}$. (A) Representative photomicrographs; (a) Control $(0 \mu \mathrm{M})$; (b) rac-PZQ (I60 $\mu \mathrm{M})$; (c) $(R)-\mathrm{PZQ}$ $(160 \mu \mathrm{M})$; and (d) $(S)$-PZQ $(160 \mu \mathrm{M})$. (B) The cell viability quantified by hoechst 33342 staining. $* * P<0.01$ in all treatment groups.

Abbreviations: $\mathrm{PZQ}$, praziquantel; rac, racemic. 
was evaluated by the quantification of plasma membrane damage that resulted in the release of lactate dehydrogenase (LDH). These compounds were dissolved in DMSO and diluted with culture medium. The cells cultured in the exponential growth phase were treated with different concentrations $(2.5 \mu \mathrm{M}, 5 \mu \mathrm{M}, 10 \mu \mathrm{M}, 20 \mu \mathrm{M}, 40 \mu \mathrm{M}, 80 \mu \mathrm{M}$, and $160 \mu \mathrm{M})$ of PZQ enantiomers at a density of $5 \times 10^{4}$ cells $/ 100 \mu \mathrm{L}$ per well and incubated for 48 hours at $37^{\circ} \mathrm{C}$ in $5 \% \mathrm{CO}_{2}$ incubator. Then, the level of LDH released in the cell culture supernatant was detected by LDH cytotoxicity assay detection kit (Beyotime Institute of Biotechnology, Jiangsu, People's Republic of China) following the manufacturer's instructions. The negative (cells and solvent) and positive (cells treated with rac-PZQ) controls were run in parallel. All assays were carried out in triplicate. The results were expressed in the cell viability rates under different drug concentrations on the four cell lines and are described in Figure 4.
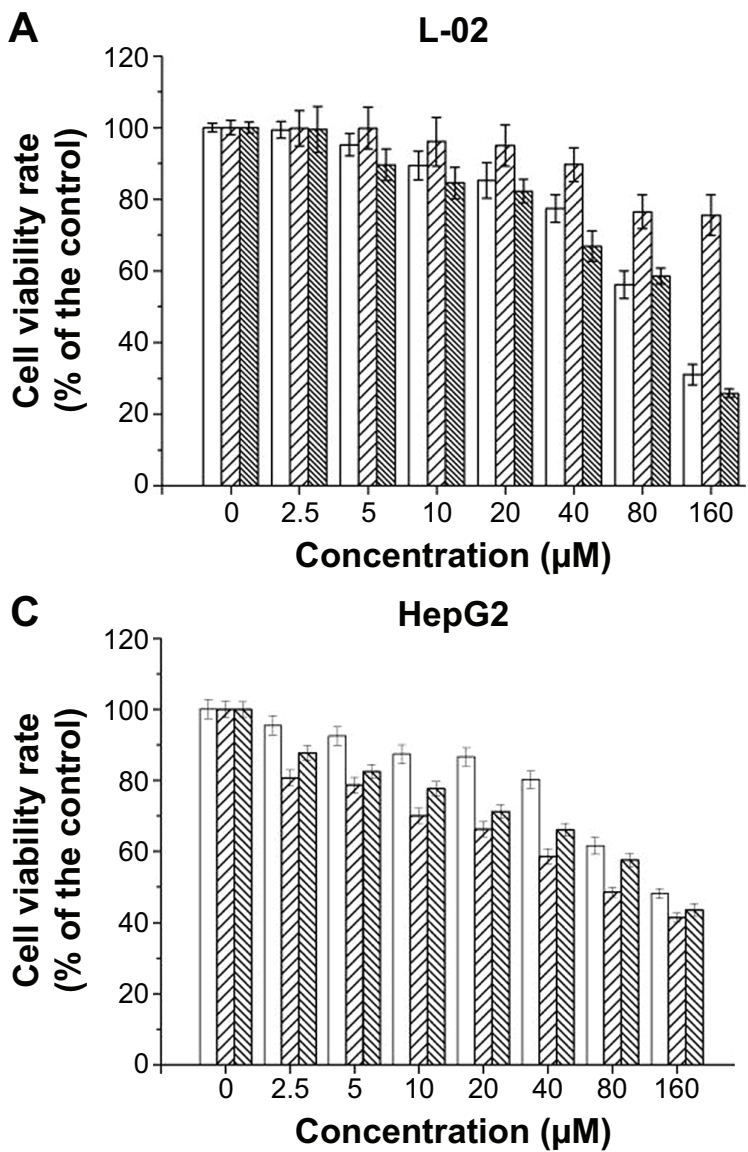

\section{Results and discussion}

Though rac-PZQ is reported to be safe and has been used for the treatment of schistosomiasis for more than 4 decades, some studies report severe adverse effects. ${ }^{18,19}$ In order to reveal which enantiomer possesses low toxicity to human definitive hosts compared with rac-PZQ, suitable cell lines are selected to study the cytotoxicity of PZQ enantiomers.

Schistosomiasis is transmitted through skin contacted with infected water. After penetrating the skin, schistosomiasis migrates to the lung, goes to the liver, and then stays there for $\sim 20$ days, where the worms grow rapidly to attain sexual maturity. Therefore, the lung and liver are the focal points of pathogenic insult and subsequent pathological damage in schistosomiasis. ${ }^{20,21}$ Therefore, human normal liver cells (L-02), human hepatocellular carcinomas (HepG2, prf-plc-5), and human lung cancer cells (A549) were chosen for evaluating the cytotoxicity of $(R)$ - and $(S)$-PZQ.
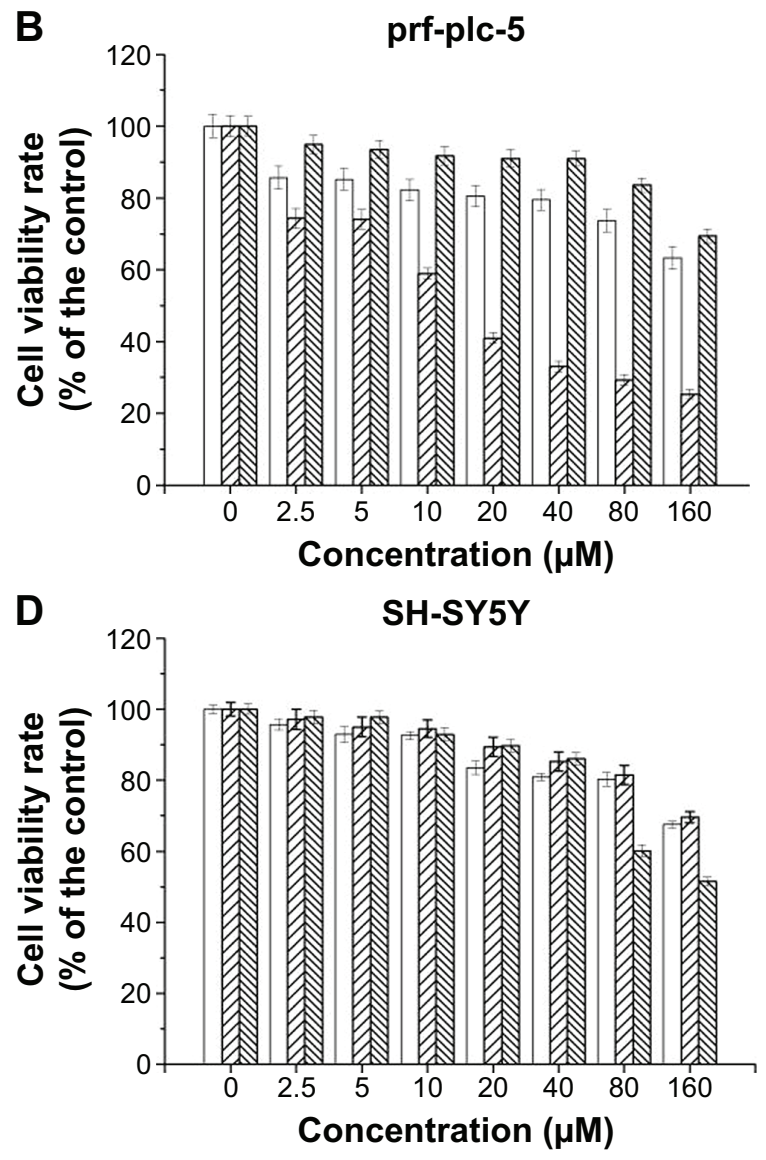

$$
\square \text { rac-PZQ (R)-PZQ } \mathbb{Z Z A}(S)-\mathrm{PZQ}
$$

Figure 4 The cell viability rate of (R)-PZQ, (S)-PZQ, and rac-PZQ assayed by LDH.

Notes: These four cell lines (the results of other four cell lines are not shown) are continuously treated with different concentrations $(2.5 \mu \mathrm{M}, 5 \mu \mathrm{M}$, $10 \mu \mathrm{M}, 20 \mu \mathrm{M}, 40 \mu \mathrm{M}$, $80 \mu \mathrm{M}, 160 \mu \mathrm{M}$ ) of PZQ enantiomers for 48 hours. (A) L-02 cell line, (B) prf-plc-5 cell line, (C) HepG2 cell line, and (D) SH-SY5Y cell line. Cell viability was then determined by $L D H$ assay. $P<0.05$ at all concentrations.

Abbreviations: PZQ, praziquantel; rac, racemic; LDH, lactate dehydrogenase. 
Furthermore, schistosomiasis is a complex syndrome affecting several organs, such as the central nervous system (CNS), and functions to different degrees ${ }^{22}$ and causes many side effects to host. ${ }^{23,24}$ Besides abdominal discomfort, particularly pain and nausea, headache, dizziness, and drowsiness may occur shortly after administering PZQ; ${ }^{21,24-26}$ these direct effects have close relationship with the nervous and digestive systems. Therefore, human neuroblastoma cell line (SH-SY5Y), the well-defined developmental model that has been widely used in experimental neurological diseases studies, ${ }^{27}$ and the human colorectal carcinoma cell line (HCT-15) were selected for the valuation of cytotoxicity study.

Schistosomiasis is characterized by hepatic granuloma formation. It has been reported ${ }^{28}$ that eggs spawned by an adult schistosome can promote proliferation of HUVECs in vitro. Hence, it is necessary to investigate the effects of PZQ on HUVECs.

In addition, it was reported ${ }^{29}$ that $r a c$-PZQ had an immune-dependent action against schistosomiasis. Rac-PZQ showed reduced efficacy in immune-suppressed animals, and the efficacy of PZQ in immune-compromised animals could be enhanced by passive transfer of either homologous immune serum or immunoglobulins purified from the immune serum. For this reason, we decided to investigate the influences of $(R)$ - and $(S)$-PZQ on murine macrophage cells (Raw264.7).

As presented in Table 1, $(R)$-PZQ, $(S)$-PZQ, and $r a c$-PZQ exhibited different activities against the eight cell lines. (R)-PZQ had negligible cytotoxicity against L-02, SH-SY5Y, HUVEC, A549, HCT-15, and Raw264.7 cells with $\mathrm{IC}_{50}>200$. Regarding the human hepatocellular carcinomas (prf-plc-5 and HepG2), (R)-PZQ exhibited higher cytotoxicity than rac-PZQ and (S)-PZQ. However, $(R)$-PZQ did not show toxicity on normal liver cells $\left(\mathrm{IC}_{50}>200 \mu \mathrm{M}\right)$, whereas rac-PZQ and (S)-PZQ showed higher toxicity against $\mathrm{L}-02$ cell line $\left(\mathrm{IC}_{50}=80.4 \pm 1.9 \mu \mathrm{M}\right.$ and $106 \pm 2.0 \mu \mathrm{M}$, respectively) than $(R)-\mathrm{PZQ}$. Since $(R)$-PZQ negligibly affected the human normal liver cells (L-02) but selectively inhibited tumor cell lines (prf-plc-5 and HepG2), we can speculate that $(R)$-PZQ has no liver toxicity, and it could contribute to the preventive treatment of hepatocellular carcinoma that is induced by schistosomiasis. Regarding the cytotoxicity on cells belonging to the nervous system, both (R)-PZQ and rac-PZQ exhibited inappreciable cytotoxicity on SH-SY5Y cells $\left(\mathrm{IC}_{50}>200\right)$, while ( $S$ )-PZQ showed some degree of toxicity with $\mathrm{IC}_{50}=196.8 \pm 4.1 \mu \mathrm{M}$. This indicated that $(S)$-PZQ is possibly the enantiomer in $r a c-\mathrm{PZQ}$ which causes the side effect on CNS, and this point deserves further investigation.

\section{Cytotoxicity by (R)-PZQ, (S)-PZQ, and rac-PZQ on hepatocytes (L-02, prf-plc-5, and HepG2)}

When the concentrations were $<40 \mu \mathrm{M},(R)-\mathrm{PZQ},(S)-\mathrm{PZQ}$, and rac-PZQ showed no inhibition on L-02 cell viability (Figure 2A), whereas rac-PZQ and (S)-PZQ showed obvious inhibition at $\geq 40 \mu \mathrm{M}$ in a concentration-dependent manner. When the concentrations were achieved to $160 \mu \mathrm{M},(S)$-PZQ and rac-PZQ exhibited significant cytotoxicity on L-02 cells and $(R)$-PZQ still showed negligible toxic activity. Regarding the tumor cell lines, $(R)$-PZQ showed obvious inhibition against prf-plc-5 cell line even at a low concentration of $10 \mu \mathrm{M}$ (Figure 2B) compared with (S)-PZQ and rac-PZQ, and the inhibitory effect of $(R)$-PZQ on HepG2 cells was slightly higher than rac-PZQ and (S)-PZQ from $0 \mu \mathrm{M}$ to $160 \mu \mathrm{M}$ (Figure 2C). These data indicate that $(R)-\mathrm{PZQ}$ selectively inhibited tumor cell lines (prf-plc-5 and HepG2) but with no toxicity on the human normal liver cells (L-02), and these results are similar with LDH assay, which reveal that $(R)$-PZQ not only does not cause damage for normal liver but also benefits the treatment of liver cancer, which might be induced by schistosomiasis. ${ }^{29,30}$

\section{Cytotoxicity by (R)-PZQ, (S)-PZQ, and rac-PZQ on SH-SY5Y cells}

It has been reported ${ }^{21,24-26}$ that PZQ can cause side effects on the nervous system. As shown in Figure 2D, $(R)-\mathrm{PZQ}$, (S)-PZQ, and rac-PZQ showed no obvious cytotoxicity on SH-SY5Y cells when the concentration was $<40 \mu \mathrm{M}$. However, after the concentration was reached to $80 \mu \mathrm{M},(S)$-PZQ showed obvious cytotoxicity on SH-SY5Y cells with lower cell viability percentage than ( $R$ )-PZQ and $r a c$-PZQ. These results demonstrate that $(S)$-PZQ should be the enantiomer in rac-PZQ which causes side effects on the CNS, especially when the high dose is administered. By this point, we can deduce that it is meaningful to clinically use $(R)-\mathrm{PZQ}$ in order to reduce the side effects caused by $(S)$-PZQ on the CNS.

\section{Cytotoxicity by (R)-PZQ, (S)-PZQ, and rac-PZQ on HUVECs}

Since schistosomiasis is characterized by hepatic granuloma formation, the endothelial cell activation may contribute to the development of granuloma and vascularization in the granuloma periphery. When schistosome matures, it spawns eggs, which stimulate the proliferation of HUVECs in vitro. ${ }^{30}$ 
Regarding HUVECs (Figure 2E), (R)-PZQ exhibited higher inhibition rate than rac-PZQ and $(S)$-PZQ in a concentrationdependent manner when the concentration reached $>2.5 \mu \mathrm{M}$. Since high inhibitory activity against HUVECs can help to prevent the hepatic granuloma formation to some degree, $(R)$-PZQ might be the main active enantiomer to hinder the hepatic granuloma formation. ${ }^{28,31,32}$

\section{Cytotoxicity by (R)-PZQ, (S)-PZQ, and rac-PZQ on $\mathrm{A} 549$ and $\mathrm{HCT}-\mathrm{I} 5$ cells}

As shown in Figure $2 \mathrm{~F}$ and $\mathrm{G}$, the compounds $(R)-\mathrm{PZQ}$, (S)-PZQ, and rac-PZQ showed negligible cytotoxicity against A549 and HCT-15 cells with low inhibition rates with the concentrations ranging from $0 \mu \mathrm{M}$ to $160 \mu \mathrm{M}$ in concentration-dependent manner. $(R)-\mathrm{PZQ}$ displayed mild cytotoxicity only at high concentrations. The side effects of $(R)-\mathrm{PZQ}$ to lungs and colons can be ignored unless very high dosage is administered in clinical therapy.

\section{Effects of (R)-PZQ, (S)-PZQ, and rac-PZQ on Raw264.7 cells proliferation}

Since $r a c$-PZQ had an immune-dependent action against schistosomiasis, ${ }^{33}$ the efficacy of PZQ in immunocompromised animals could be enhanced by passive transfer of either homologous immune serum or immunoglobulins purified from the immune serum. The study of the activity of these three compounds on Raw264.7 cells showed that both $(R)$-PZQ and rac-PZQ could promote the growth of Raw264.7 cells with the concentrations ranging from $2.5 \mu \mathrm{M}$ to $40 \mu \mathrm{M}$ (Figure $2 \mathrm{H}$ ) and had no toxicity on Raw264.7 cells even when the concentration reached $160 \mu \mathrm{M}$. On the contrary, $(S)-\mathrm{PZQ}$ could inhibit proliferation of Raw264.7 cells from $20 \mu \mathrm{M}$ to $160 \mu \mathrm{M}$ with moderate toxicity. This result proved that $(R)$-PZQ should be the isomer in rac-PZQ to cause immune-dependent action.

\section{Fluorescent microscopic analysis of cell apoptosis by Hoechst 33342 staining}

Based on the MTT assay, the compounds (R)-PZQ, (S)-PZQ, and $r a c$-PZQ displayed considerably different cytotoxicity against L-02, prf-plc-5, HepG2, and SH-SY5Y cells. These four cell lines were selected for cell morphological assessment by Hoechst 33342 staining. The normal cells showed pale blue fluorescence, and the apoptotic cells showed strong blue fluorescence. As illustrated in Figure 3, almost all the cells in group a (control) showed round and homogeneous pale blue fluorescence, whereas a large number of cells exhibited brilliant blue staining in groups b, c, and d (treated with rac-PZQ, (R)-PZQ, and (S)-PZQ, respectively). On L-02 cells, the number of apoptotic cells with strong staining in group c was far less than those in groups b and $d$. On the contrary, in terms of prf-plc-5 and HepG2 cell lines, large amounts of apoptotic cells could be observed in group c. In the case of SH-SY5Y cells, the number of cells that exhibited strong blue staining was much more in group $d$ than those in groups $\mathrm{c}$ and $\mathrm{b}$. These results are consistent with those from LDH test (Figure 4) and MTT assay.

\section{Conclusion}

Our study clearly demonstrated that $(R)$-PZQ has ignorable toxicities on many kinds of human cell lines related with schistosomiasis, while $(S)$-PZQ is the undesirable isomer in rac-PZQ. Combining the previous studies about the metabolism differences of PZQ enantiomers, ${ }^{16}$ the taste of $(R)-\mathrm{PZQ}$ and $(S)-\mathrm{PZQ},{ }^{15}$ and the therapeutic efficacy and side effects of (R)-PZQ and rac-PZQ, ${ }^{14}$ exclusion of $(S)$-PZQ from rac-PZQ is necessary and the use of pure $(R)-\mathrm{PZQ}$ in clinical therapy is highly imperative.

\section{Acknowledgment}

This work was partly funded by the National High-Tech Program of China (863 Program, 2012AA020306).

\section{Disclosure}

The authors report no conflicts of interest in this work.

\section{References}

1. Chitsulo L, Engels D, Montresor A, Savioli L. The global status of schistosomiasis and its control. Acta Trop. 2000;77(1):41-51.

2. Gryseels B. Schistosomiasis. Infect Dis Clin North Am. 2012;26(2): 383-397.

3. Caffrey CR. Chemotherapy of schistosomiasis: present and future. Curr Opin Chem Biol. 2007;11(4):433-439.

4. Caffrey CR, Williams DL, Todd MH, Nelson DL, Keiser J, Utzinger J. Chemotherapeutic Development Strategies for Schistosomiasis. New York, NY: Wiley Blackwell; 2009:299-321.

5. Watkins BM. Drugs for the control of parasitic diseases: current status and development. Trends Parasitol. 2003;19(11):477-478.

6. Doenhoff MJ, Kusel JR, Coles GC, Cioli D. Resistance of Schistosoma mansoni to praziquantel: is there a problem? Trans R Soc Trop Med Hyg 2002;96(5):465-469.

7. Fallon PG, Doenhoff MJ. Drug-resistant schistosomiasis: resistance to praziquantel and oxamniquine induced in Schistosoma mansoni in mice is drug specific. Am J Trop Med Hyg. 1994;51(1):83-88.

8. Liang YS, Wang W, Dai JR, et al. Susceptibility to praziquantel of male and female cercariae of praziquantel-resistant and susceptible isolates of Schistosoma mansoni. J Helminthol. 2010;84(2):202-207.

9. Melman SD, Steinauer ML, Cunningham C, et al. Reduced susceptibility to praziquantel among naturally occurring Kenyan isolates of Schistosoma mansoni. PLoS Negl Trop Dis. 2009;3(8):e504.

10. Wang W, Wang L, Liang YS. Susceptibility or resistance of praziquantel in human schistosomiasis: a review parasitology research. Parasitol Res. 2012;111(5):1871-1877. 
11. Xiao S, You J, Mei J, Hu Y, Zhou D, Catto BA. In vitro and in vivo effect of levopraziquantel, dextropraziquantel versus racemic praziquantel on different developmental stages of Schistosoma japonicum. Chin J Parasitol Parasit Dis. 1998;16(5):335-341.

12. WHO/TDR [webpage on the Internet]. BL6 Business Plan 2008-2013; 2007. Available from: http:/www.who.int/tdr/publications/documents/ bl6-business-plan.pdf. Accessed Sept 1, 2008.

13. Woelfle M, Seerden JP, de Gooijer J, Pouwer K, Olliaro P, Todd MH. Resolution of praziquantel. PLOS Negl Trop Dis. 2011;5(9):e1260.

14. Wu MH, Wei CC, Xu ZY, et al. Comparison of the therapeutic efficacy and side effects of single dose of levo-praziquantel with mixed isomer praziquantel in 278 cases of Schistosomiasis japonica. Am J Trop Med Hyg. 1991;45(3):345-349.

15. Meyer T, Sekljic H, Fuchs S, Othe H, Schollmeyer D, Miculka C. Taste, a new incentive to switch to $(R)$-praziquantel in schistosomiasis treatment. PLOS Negl Trop Dis. 2009;3(1):e357.

16. Wang H, Fang ZZ, Zheng Y, et al. Metabolic profiling of praziquantel enantiomers. Biochem Pharmacol. 2014;90(2):166-178.

17. Zheng Y, Dong LL, Hu CY, et al. Development of chiral praziquantel analogues as potential drug candidates with activity to juvenile Schistosoma japonicum. Bioorg Med Chem. 2014;24(17):4223-4226.

18. Berhe N, Gundersen SG, Abebe F, Birrie H, Medhin G, Gemetchu TV. Praziquantel side effects and efficacy related to Schistosoma mansoni egg loads and morbidity in primary school children in north-east Ethiopia. Acta Trop. 1999;72(1):53-63.

19. Kabatereine NB, Kemijumbi J, Ouma JH, et al. Efficacy and side effects of praziquantel treatment in a highly endemic Schistosoma mansoni focus at Lake Albert, Uganda. Trans R Soc Trop Med Hyg. 2003;97(5): 599-603.

20. de Oliveira RB, Senger MR, Vasques LM, et al. Schistosoma mansoni infection causes oxidative stress and alters receptor for advanced glycation endproduct (RAGE) and tau levels in multiple organs in mice. Int J Parasitol. 2013;43(5):371-379.

21. Abdel-Hafeez EH, Ahmad AK, Abdulla AM, Aabdel-Wahab S, Mosalem FA. Therapeutic effect of alpha lipoic acid combined with praziquantel on liver fibrosis induced by Schistosoma mansoni challenged mice. Parasitol Res. 2012;111(2):577-586.
22. Li Y, Ross AG, Hou X, Lou Z, McManus DP. Oriental schistosomiasis with neurological complications: case report. Ann Clin Microbiol Antimicrob. 2011;10:5.

23. Barron L, Wynn TA. Macrophage activation governs schistosomiasisinduced inflammation and fibrosis. J Immunol. 2011;41(9): 2509-2514.

24. Gryseels B, Polman K, Clerinx J, Kestens L. Human schistosomiasis. Lancet. 2006;368(9541):1106-1118.

25. Raso G, N'Goran EK, Toty A, et al. Efficacy and side effects of praziquantel against Schistosoma mansoni in a community of western Cote d'Ivoire. Trans R Soc Trop Med Hyg. 2004;98(1):18-27.

26. Useh MF. Control of schistosomiasis. Schistosomiasis. 2012:210.

27. Powers CM, Wrench N, Ryde IT, Smith AM, Seidler FJ, Slotkin TA. Silver impairs neurodevelopment: studies in PC12 cells. Environ Health Perspect. 2010;118(1):73-79.

28. Loeffler DA, Lundy SK, Singh KP, Gerard HC, Hudson AP, Boros DL. Soluble egg antigens from Schistosoma mansoni induce angiogenesisrelated processes by up-regulating vascular endothelial growth factor in human endothelial cells. J Infect Dis. 2002;185(11):1650-1656.

29. Fallon PG, Cooper RO, Probert AJ, Doenhoff MJ. Immune-dependent chemotherapy of schistosomiasis. Parasitology. 1992;105(Suppl): S41-S48.

30. Qiu DC, Hubbard AE, Zhong B, Zhang Y, Spear RC. A matched casecontrol study of the association between Schistosoma japonicum and liver and colon cancers in rural China. Ann Trop Med Parasitol. 2005;99(1): 47-52.

31. Peng YZ, Jia H, Zhang RL, et al. Molecular etiology of rectal cancer in patients with Schistosoma japonicum. Chin Trop Med. 2003;3: 137-140.

32. Gakuhei S, Hines IN, Jeff L, Schrum LW, Richard A. Rippe inhibition of phosphatidylinositol 3-kinase signaling in hepatic stellate cells blocks the progression of hepatic fibrosis. Hepatology. 2009;50(5): 1512-1523.

33. Pötgens AJ, Lubsen NH, van Altena MC, Schoenmakers JG, Ruiter DJ, de Waal RM. Vascular permeability factor expression influences tumor angiogenesis in human melanoma lines xenografted to nude mice. Am J Pathol. 1995;146(1):197-209.
Drug Design, Development and Therapy

\section{Publish your work in this journal}

Drug Design, Development and Therapy is an international, peerreviewed open-access journal that spans the spectrum of drug design and development through to clinical applications. Clinical outcomes, patient safety, and programs for the development and effective, safe, and sustained use of medicines are a feature of the journal, which

\section{Dovepress}

has also been accepted for indexing on PubMed Central. The manuscript management system is completely online and includes a very quick and fair peer-review system, which is all easy to use. Visit http://www.dovepress.com/testimonials.php to read real quotes from published authors. 